\title{
RBMS1 Gene
}

National Cancer Institute

\section{Source}

National Cancer Institute. RBMS1 Gene. NCI Thesaurus. Code C114445.

This gene is involved in both DNA replication and single-stranded DNA binding. 